\title{
Domestic Investment, Foreign Direct Investment, and Economic Growth Nexus: A Case of Pakistan
}

\author{
Irfan Ullah, Mahmood Shah, and Farid Ullah Khan \\ Department of Economics, Gomal University, D.I. Khan 29050, Pakistan \\ Correspondence should be addressed to Irfan Ullah; irfanecon@gmail.com
}

Received 18 April 2014; Accepted 11 June 2014; Published 29 June 2014

Academic Editor: Raouf Boucekkine

Copyright (C) 2014 Irfan Ullah et al. This is an open access article distributed under the Creative Commons Attribution License, which permits unrestricted use, distribution, and reproduction in any medium, provided the original work is properly cited.

This study aims to find dynamic interaction between domestic investment, foreign direct investment, and economic growth in Pakistan for the period 1976-2010. Phillips and Perron (PP) test is used to assess unit root in the concerned data series. Johansen cointegration approach applied to examine the long run relationship and Toda-Yamamoto causality approach is exercised to evaluate causal linkages. Besides foreign direct investment inflow to Pakistan and domestic investments variables, this study also used GDP as a third variable in order to avoid misspecification problems in the model and also to know the interrelationship between the variables. The empirical findings of this study reveal the existence of long run relationship between domestic investments, foreign direct investment, and economic growth, further supported by Toda-Yamamoto causality, and bidirectional causality has been found between FDI and domestic investment implying that both domestic investment and FDI cause each other.

\section{Introduction}

The inflow of foreign capital, in the form of foreign direct investment (FDI), has considerably increased in developing countries during the last few decades. FDI inflow fulfills the rising investment requirements to boost economic growth at higher pace and helps for macroeconomic stability in the economy. This nondebt foreign inflow eases the pressure on balance of payment distortion. Technological transfer from developed countries to developing countries occurs through FDI which paves the way for economic development in developing countries. Choong and Lim [1] argue that FDI affects economic development of the recipient country at macroand microlevel. At macrolevel, it is beneficial for real sectors of the economy, for example, investment, exports, economic growth, and so forth, whereas, at microlevel, it creates technological spillover and training of manpower and enhances management skill and so forth.

Interaction between foreign and domestic investment is of paramount importance and both can cause each other in an economy. The increase in private investment signals high return on investment in the domestic economy whereas public investment shows the improvement in infrastructure and thereby reduction in cost of doing business. These roles of domestic investment motivate the foreign investors to reap the benefits of high return [2]. However foreign capital inflow may also be beneficial for the investors of host country. The impact of FDI on domestic investment is ambiguous; that is, FDI may have crowding out or crowding in impact on domestic investment. Crowding out impact of FDI means it is meaningless for FDI recipient country but crowding in impact of FDI on domestic investment is beneficial for the host country.

Like other developing countries, Pakistan is also a recipient country of bulky FDI inflow since more than three decades. This is an important source of external finance considering the deteriorated position of balance of payment. Moreover, FDI minimizes the dependence on foreign debt. Although considerable FDI inflow has been recorded in last many years, this is far less compared to other developing countries. Pakistan is also enjoying the foreign direct investment inflow during the past three to four decades. The implication of FDI has crucial importance for developing economies like Pakistan because if it crowds out the domestic investment, it will squeeze the growth of the domestic capital stock; alternatively if it crowds in the domestic investment, it 
will expand the domestic investment. Therefore it is highly desirable to test whether FDI crowds in or crowds out the domestic investment-this paper is also trying to assess the interaction between the domestic capital stock and FDI; additionally GDP is used as a third variable in the model in order to avert the misspecification problems. The remainder of the paper is as follows. Section 2 reviews empirical literature whereas Section 3 discusses methodology and data issues. Section 4 presents empirical results and summary and conclusion is given at the last section.

\section{Review of the Literature}

The study of Agarwal [3] analyzed the impact of FDI on economic growth in South Asian economies. The empirical outcomes of his study reveal a positive association between domestic investment, FDI, and GDP. The study concluded that increase in FDI in South Asian countries has manifold implication mainly due to low ownership restrictions. Indeed he found that FDI contribution to GDP growth is greater than the equal amount of foreign borrowing. Therefore his study supports more liberal policies towards FDI inflow; however, FDI is not favorable under all the conditions.

Goedegebuure [4] analyzed relationship between FDI and domestic investment. His study divided domestic investment into research and development (R\&D) and capital investment (equipment, machinery). The analyses were comprised of the industry level (cross-sectional) and company level (longitudinal). He empirically verified that $\mathrm{R} \& \mathrm{D}$ is positively related with outward FDI and has strong positive association especially in high tech industries but it is inconclusive for the capital investment. The positive contribution of FDI outbound to the domestic economy mainly emerged from supportive role for domestic R\&D.

Khan [5] also analyzed relationship between FDI, economic growth, and role of domestic financial system in case of Pakistan for the period 1972-2005. The used autoregressive distributed lag (ARDL) to cointegration approach for the empirical assessment found negative relation between FDI and domestic capital stocks (investment) in short run while in long run it became positive. Domestic facilities including infrastructure, financial sector, and macroeconomic stability can play essential role in augmenting FDI in the host country.

Falki [6] analyzed the effect of FDI on economic growth in case of Pakistan and used endogenous growth model in her study and incorporated other variables that affect production including trade, domestic capital, and labor. The model is estimated via OLS, unit root, and cointegration techniques. She showed a negative and insignificant relationship between GDP and FDI in Pakistan. She suggests that more Greenfield investment along with large scale manufacturing investment could improve export sector and would cause the FDI inflow to the country. Additionally government should need to improve infrastructure and human resources, strengthen the local entrepreneurship, and provide suitable macroeconomic environment; all of these incentives will bring the FDI inflow to the country and will cause positive significant implication for the growth.
Ghazali [7] in his paper analyzed the relationship between FDI, domestic investment, and economic growth in Pakistan. The empirical findings of his paper indicated FDI, domestic capital stock, and economic growth have long run relationship and the causality analysis shows bidirectional causality between FDI and domestic investment. A unidirectional causality is found between FDI and economic growth and all these findings show that FDI supports both domestic investment and economic growth in Pakistan.

Study made by Eregha [8] for African countries reveals that although the FDI inflow to Africa is low, FDI has a positive impact on domestic investment and economic growth. The study also adds that FDI inflow primarily depends on the country's policies infrastructure, institutions, reliability, and consistent financial sector. Foreign direct investment generally considers infringing the domestic investment. The bivariate and multivariate estimations of this study also pointed that FDI crowds out the domestic investment. The conclusion of his study supports Braunstein and Epstein [9], Kumar and Pradhan [10], Fedderke and Romm [11], Titarenko [12], Udomkerdmongkol and Morrissey [13], and Adams [14].

Rizvi [15] examined relationship between socioeconomic development and FDI in Pakistan for the period 1979-2008. He used autoregressive distributed lag model (ARDL) and confirmed that FDI and socioeconomic development are correlated in the long run. Causality analysis is performed for the direction of causality, and unidirectional causality from socioeconomic development to FDI is found implying that FDI does not cause socioeconomic development, while socioeconomic development causes foreign direct investment in case of Pakistan. The results of the study support Siddharthan [16] findings and development is prerequisite for the attraction of FDI.

\section{Methodology and Data}

3.1. Methodology. Chronological ordered annual macroeconomic time series data may be nonstationary. Nonstationarity in the series means that the series contain permanent stochastic trend which, continues over the period. Therefore, there is a prerequisite to analyze that whether the concerned time series data are stationary or not. Numbers of unit root tests are available in the literature to examine the stationarity in the data like Phillips and Perron test, Augmented Dickey Fuller test, NG-Perron test etc. This study applies Phillips and Perron (PP) unit root test before applying econometric technique for empirical analysis which has been extensively applied in empirical literature.

The aim of this study is to find causality between FDI and domestic investment and for this purpose Granger [17] causality test is valid provided that all the series are stationary at level. However, if the variables contain unit root at level and become stationary at first differenced that is, $I(1)$, then cointegration may prevail between/among the variables [18]. Johansen and Juselius [19] devised a test to examine cointegration Engle and Granger Cointegration test is more appropriate if the model of two variables is used. However, if there is multivariate model, there is a possibility that more than one 
cointegration relationship prevails in the model. Johansen cointegration test helps to find more than one cointegration vectors, if exists in the model.

This test is based on the following equation:

$$
\Delta \Upsilon_{t}=\Pi \Upsilon_{t-1}+\sum_{i=1}^{p-1} \Gamma_{i} \Delta \Upsilon_{t-i}+\varepsilon_{t}
$$

where

$$
\begin{gathered}
\Pi=-\left(I-\sum_{i=1}^{p-1} A_{i}\right) \\
\Gamma_{i}=-\sum_{j=i+1}^{p} A_{j} .
\end{gathered}
$$

The ranks in the matrix $\Pi$ help to find cointegration in the model. If there is no rank $(r)-r=0$, it can be concluded that there is no cointegration. But, if there is $r \leq(n-1)$, it means that $(n-1)$ cointegration relationships exist in the model. The ranks are sorted with the help of values of the maximum eigenvalue and trace statistics.

Causal link can be found through Johansen cointegration test based vector error correction model (VECM) provided that cointegration prevails among the variables. However, application of VECM is a complex procedure and associated with cumbersome process [20]. Toda and Yamamoto [21] devised a causality test which is applicable irrespective of having the series cointegrated or not. This test is based on augmented VAR $\left(k+d_{\max }\right)$. In augmented VAR $(k+$ $\left.d_{\max }\right) k$ shows the lags of variables which can be determined through lag selection criteria, whereas $d_{\max }$ means maximum integration order. Tang [22] argued that this augmented VAR can be jointly estimated through "seemingly unrelated regression (SUR) technique because this technique estimates efficient results. After estimating the VAR based on the above specification, standard Wald test restriction can be imposed on the $\operatorname{lag}(k)$ in order to assess causal linkage.

3.2. Data. This study used the following variables to find the relationship between domestic investment and foreign direct investment in Pakistan:

LNFDI = natural logarithm of foreign direct investment,

LNDINV = natural logarithm of gross fixed capital formation (GFCF),

LNGDP = natural logarithm of gross domestic product.

Besides domestic investment and foreign direct investment inflow variables, we use GDP variable in the model in order to avoid misspecification problem. The time period of this study is 2006-2010. All these three variables are used and transformed into real form through GDP deflator $=2000-01$ which further transformed into natural logarithm form. The data on FDI are taken from World Bank Data [23] source whereas data on GDP, GFCF and GDP are collected from Hand Book of Pakistan Economy [24], published by State Bank of Pakistan.
TABLE 1: Results of PP unit root tests.

\begin{tabular}{lcc}
\hline Variables & With constant & With constant and trend \\
\hline LNFDI & -2.86 & -3.31 \\
LNDINV & -1.32 & -2.18 \\
LNGDP & -1.89 & -2.80 \\
$\Delta$ LNFDI & $-6.82^{*}$ & $-6.84^{*}$ \\
$\Delta$ LNDINV & $-4.51^{*}$ & $-4.53^{*}$ \\
$\Delta$ LNGDP & $-8.12^{*}$ & $-11.03^{*}$ \\
\hline
\end{tabular}

Note: critical values for constant at $1 \%$ and $5 \%$ are -3.64 and -2.95 whereas values for constant with trend are -4.25 and -3.55 .

${ }^{*}$ show significant at 1 percent level.

TABLE 2: Johansen cointegration test: results of trace stat value.

\begin{tabular}{llcl}
\hline$H_{0}$ & $H_{1}$ & $\lambda$-trace & $95 \% \mathrm{CV}$ \\
\hline$r=0$ & $r \geq 1$ & $54.60465^{*}$ & 42.91525 \\
$r \leq 1$ & $r \geq 2$ & 25.33604 & 25.87211 \\
$r \leq 2$ & $r \geq 3$ & 12.25047 & 12.51798 \\
\hline
\end{tabular}

* show significant at 1 percent level.

TABLE 3: Johansen cointegration test: results of maximum-Eigen stat.

\begin{tabular}{llcl}
\hline$H_{0}$ & $H_{1}$ & $\lambda-\max$ & $95 \% \mathrm{CV}$ \\
\hline$r=0$ & $r=1$ & $29.26861^{*}$ & 25.82321 \\
$r \leq 1$ & $r=2$ & 13.08557 & 19.39704 \\
$r \leq 2$ & $r=3$ & 12.25047 & 12.51798 \\
\hline
\end{tabular}

* show significant at 1 percent level.

\section{Empirical Results}

First of all, PP unit root test is applied on all three data series in order to examine stationarity of the data. This test is based on the null hypothesis of unit root against the alternate hypothesis of no unit roots. The results of unit root analysis are given in Table 1 which shows all the series at nonstationary at level because null hypotheses for all the series are not rejected at 5 percent level significance in only constant and constant with trend cases. However, all three variables are stationary at first differenced; $I(1)$ as the null hypotheses of unit roots at differenced are rejected at 1 percent significant level for both constant as well as constant with trend case. This analysis shows that no data series is stationary at level but stationary at first differenced; therefore, these variables may contain long run relationship among them. Keeping this view, we apply Johansen cointegration approach to find long run relation.

Before application of Johansen cointegration test, it is important to find the lag length of the VAR through some lag selection criteria in order to have parsimonious model. Numbers of lag selection criteria have been used in the literature, e.g., Akaike Information Criterion (AIK), Hannan-Quinn information Criterion (HQ), Sequential modified LR test statistics, Schwarz Information Criterion (SIC), Final Prediction Error (FPE). However, one or more than criteria may be used for lag selection. Schwarz information criterion (SIC), final prediction error (FPE), and Hannan-Quinn information 
TABLE 4: Results of Toda-Yamamoto causality test results.

\begin{tabular}{lcc}
\hline Null hypothesis & Modified Wald statistics (probability) & Conclusion \\
\hline LNDINV does not cause LNFDI & $\begin{array}{l}3.977^{* *} \\
(0.046)\end{array}$ & Null hypothesis is rejected \\
\hline LNFDI does not cause LNDINV & $\begin{array}{l}4.803^{* *} \\
(0.028)\end{array}$ & Null hypothesis is rejected \\
\hline LNDINV does not cause LNGDP & $\begin{array}{l}4.233^{* *} \\
(0.0396)\end{array}$ & Null hypothesis is rejected \\
\hline LNGDP does not cause LNDINV & $\begin{array}{l}0.253 \\
(0.615)\end{array}$ & Null hypothesis is accepted \\
\hline \multirow{2}{*}{ LNGDP does not cause LNFDI } & $\begin{array}{l}3.286^{* * *} \\
(0.0699)\end{array}$ & Null hypothesis is rejected \\
\hline \multirow{2}{*}{ LNFDI does not cause LNGDP } & $\begin{array}{l}1.358 \\
(0.244)\end{array}$ & Null hypothesis is accepted \\
\hline
\end{tabular}

Note: ${ }^{* * * * *}$ denotes statistically significant at 5 percent and 10 percent, respectively.

criterion (HQ) confirm lag length one (1). After ascertaining lag length, we apply Johansen cointegration test and the results of this test are given at Tables 2 and 3 . Table 2 shows the results of trace statistic whereas Table 3 presents the results of maximum Eigen statistics. Trace statistics and maximum Eigen statistics values help to find the $\operatorname{rank}(\mathrm{s})$ which shows the number of vector(s) containing long run relations. It is evident from Table 2 that the null hypothesis of no rank is rejected at 1 percent significant level. Moreover, the results of Table 3 reveal that null hypothesis of no rank was also rejected at 1 percent level of significance. Therefore, the results of both trace and max-Eigen statistics confirm that one cointegration vector exists in the model. It means long run relationship prevails among the variables.

Causal linkage between domestic investment and foreign direct investment is estimated through Toda and Yamamoto [21] approach. Order of integration and lag length are incorporated to prepare the system of equations which are estimated with "seemingly unrelated regression equation (SURE). As already explained, all the variables are integrated at first order and lags length of the variables is one as per different lag length selection criteria. The results of the causality are presented in Table 4 which shows that domestic investment causes foreign direct investment in Pakistan because the null hypothesis is reject at 5 percent significant level. Reverse causality from foreign direct investment to direct investment also exists and the null hypothesis of this case is also rejected at 5 percent level of significance. It means that both domestic investment and foreign direct investment inflow cause each other in Pakistan. This table also illumines that domestic investment causes economic growth in Pakistan; however, economic growth does not cause domestic investment. This analysis reveals that there is unidirectional causality from domestic investment from economic growth for Pakistan. In addition to that, there is unidirectional causality from economic growth to foreign direct investment because null hypothesis of this case is also rejected at 10 percent significant level. To conclude, this study found bidirectional causal association between domestic investment and foreign direct investment whereas domestic investment causes economic growth and economic growth causes foreign direct investment in Pakistan.

\section{Summary and Conclusions}

This study examines the dynamic interaction between domestic investment and foreign direct investment in case of Pakistan for the period from 1976 to 2010. The inflow of foreign direct investment from developed to developing countries increased during last few decades. Pakistan is also enjoying the foreign direct investment inflow during the past three to four decades. Phillips and Perron (PP) test is used to assess unit root in the concerned data series. Johansen cointegration approach applied to examine the long run relationship and Toda-Yamamoto causality approach is exercised to evaluate causal linkages. Besides foreign direct investment inflow to Pakistan and domestic investments variables, this study also used GDP as a third variable in order to avoid misspecification problems in the model and also to know the interrelationship between the variables. PP unit root test shows that all the variables are nonstationary at level and, however, stationary at first differenced which shows that all the variables are integrated at first order, that is, $I(1)$. Johansen cointegration test reveals that long run relationship prevails among the variables. To find causal linkage, this study applied Toda-Yamamoto causality technique, which shows that there is bidirectional causal linkage between foreign direct investment and domestic investment in Pakistan. Causality also exists from domestic investment to economic growth and from economic growth to foreign direct investment inflow in Pakistan. The study suggests that foreign direct investment could be used to supplement the domestic investment and it holds a complementary status that the reverse is also having same implication. Therefore various incentives including tax cut or subsides should be promoted by the government in order to foster the foreign direct investment and hence domestic investment. 


\section{Conflict of Interests}

The authors declare that there is no conflict of interests regarding the publication of this paper.

\section{References}

[1] C. K. Choong and K. P. Lim, "Foreign direct investment, financial development and economic growth: the case of Malaysia," Macroeconomics and Finance in Emerging Market Economies, vol. 2, no. 1, pp. 13-30, 2009.

[2] L. Ndikumana and S. Verick, "The linkages between FDI and domestic investment: unraveling the developmental impact of foreign investment in Sub-Saharan Africa," IZA Discussion Paper 3296, The institute for the Study of Labor (IZA),, Bonn, Germany, 2008.

[3] P. Agarwal, "Economic Impact of Foreign direct investment in South Asia," Working Paper, Indira Gandhi Institute of Development Research, Mumbai, India, 2000.

[4] R. V. Goedegebuure, "The effects of outward foreign direct investment on domestic investment," Investment Management and Financial Innovations, vol. 3, no. 1, 2006.

[5] M. A. Khan, "Foreign direct investment and economic growth: the role of domestic financial sector," Working Paper 18, Pakistan Institute of Development Economics, Islamabad, Pakistan, 2007.

[6] N. Falki, "Impact of foreign direct investment on economic growth in Pakistan," International Review of Business Research Papers, vol. 5, no. 5, pp. 110-120, 2009.

[7] A. Ghazali, "Analyzing the relationship between foreign direct investment domestic investment and economic growth for Pakistan," International Research Journal of Finance and Economics, vol. 47, pp. 127-135, 2010.

[8] P. Eregha, "The dynamic linkages between foreign direct investment and domestic investment in ECOWAS countries: a panel cointegration analysis," in Proceedings of the Conference of the Centre for the Study of African Economics, Oxford University, Oxford, UK, March 2011.

[9] E. Braunstein and G. Epstein, "Bargaining power and foreign direct investment in China: can 1.3 billions consumers tame the multinationals?" CEPA Working Paper 2002/13, Center for Economic Policy Analysis, New York, NY, USA, 2002.

[10] N. Kumar and J. P. Pradhan, "FDI, externalities and economic growth in developing countries. Some empirical explorations and implications for WTO negotiations on investment," RIS Discussion Paper 27, 2002.

[11] J. W. Fedderke and A. T. Romm, "Growth impact and determinants of foreign direct investment into South Africa, 19562003," Economic Modelling, vol. 23, no. 5, pp. 738-760, 2006.

[12] D. Titarenko, "The influence of foreign direct investment on domestic investment processes in Latvia," Transport and Telecommunication, vol. 7, no. 1, pp. 76-83, 2006.

[13] M. Udomkerdmongkol and O. Morrissey, "Political regime, private investment and foreign direct invesment in developing countries," UNU-WIDER Research Paper 2008/109, 2008.

[14] S. Adams, "Foreign direct investment, domestic investment, and economic growth in Sub-Saharan Africa," Journal of Policy Modeling, vol. 31, no. 6, pp. 939-949, 2009.

[15] S. A. Rizvi, "Relationship between socio-economic development and foreign direct investment: empirical evidence from Pakistan," Pakistan Business Review, vol. 11, no. 4, pp. 804-823, 2010.
[16] N. S. Siddharthan, "Regional Differences in FDI Inflows: chinaIndia Comparison," 2006.

[17] C. W. J. Granger, "Investigating causal relations by econometric models and cross-spectral methods," Econometrica, vol. 37, no. 3, pp. 424-438, 1969.

[18] R. F. Engle and C. W. Granger, "Cointegration and error correction: representation, estimation, and testing," Econometrica, vol. 55, no. 2, pp. 251-276, 1987.

[19] S. Johansen and K. Juselius, "Maximum likelihood estimation and inference on co-integration with application to the demand for money," Oxford Bulletin of Economics and Statistics, vol. 52, no. 2, pp. 169-209, 1990.

[20] N. S. Shirazi and T. A. Abdul Manap, "Exports and economic growth nexus: The case of Pakistan," Pakistan Development Review, vol. 43, no. 4, pp. 563-581, 2004.

[21] H. Y. Toda and T. Yamamoto, "Statistical inference in vector autoregressions with possibly integrated processes," Journal of Econometrics, vol. 66, no. 1-2, pp. 225-250, 1995.

[22] C. Tang, "An empirical modelling on savings behaviour in malaysia," Labuan Bulletin of International Business \& Finance, vol. 6, pp. 57-76, 2008.

[23] World Bank, Various Issues, World Development Indicators, World Bank, Washington, DC, USA, 2010.

[24] State Bank of Pakistan, Hand Book of Pakistan Economy, State Bank of Pakistan, Karachi, Pakistan, 2010. 

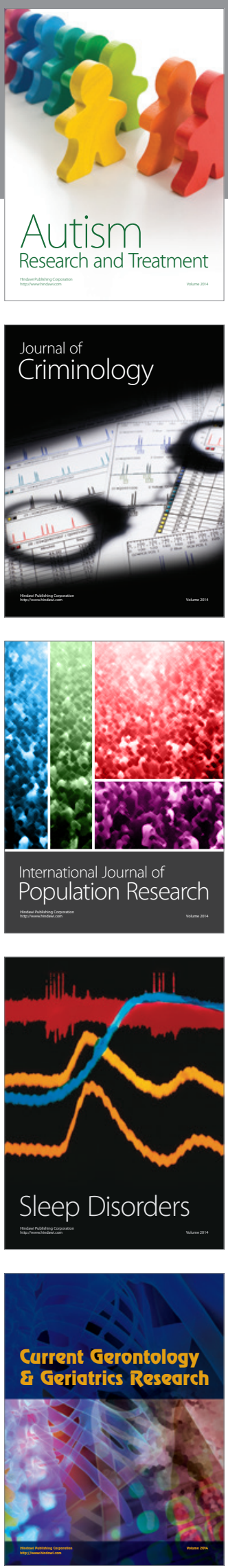
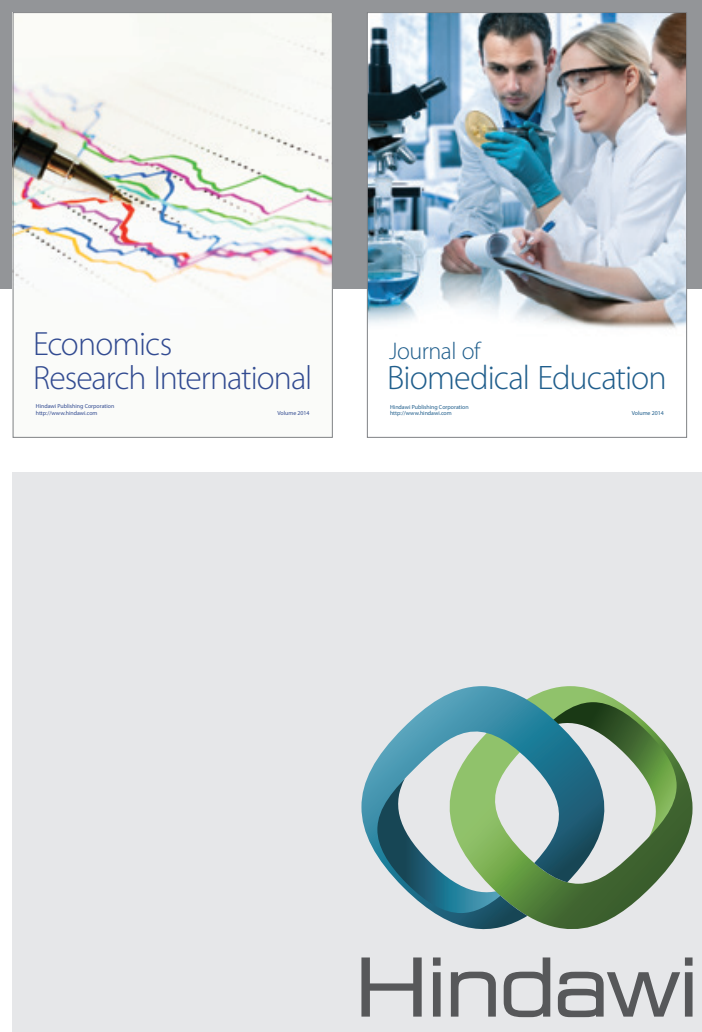

Submit your manuscripts at

http://www.hindawi.com
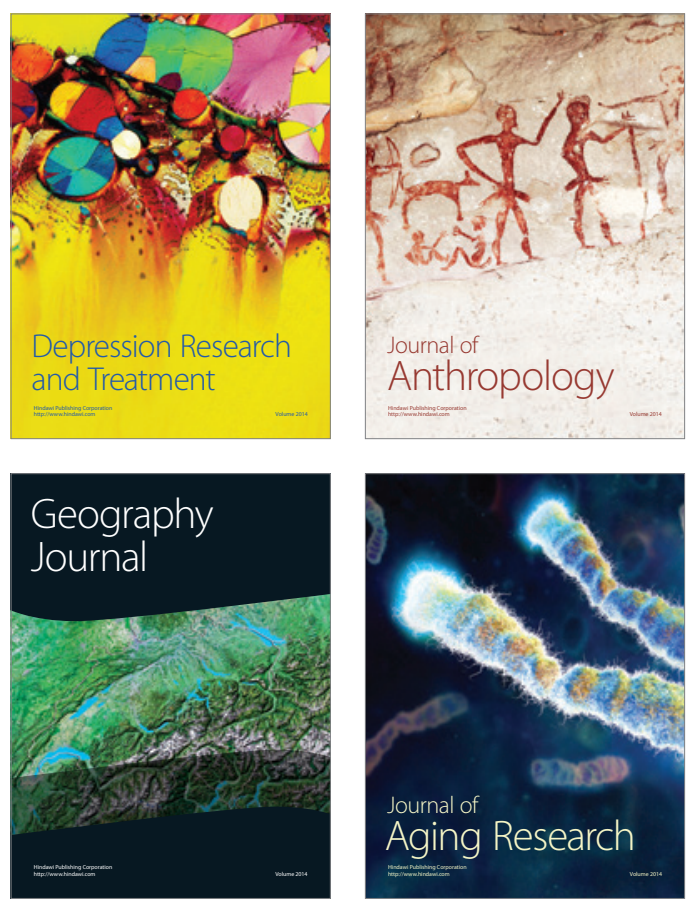
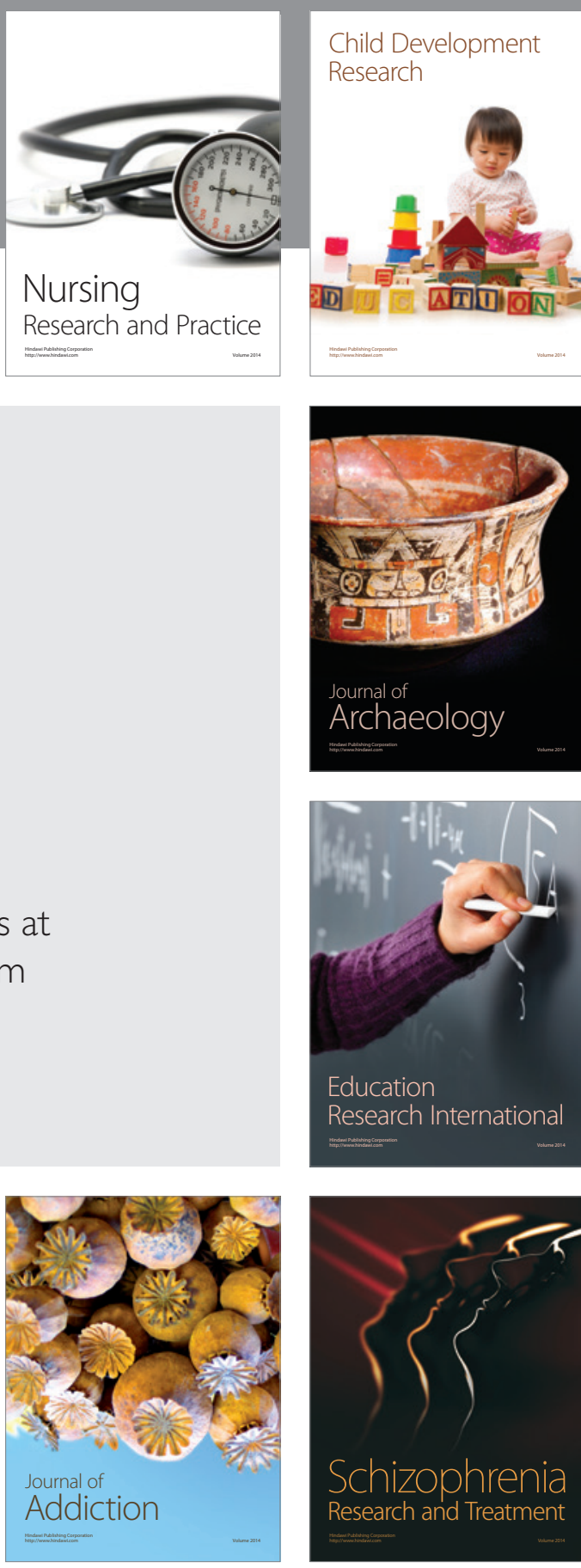

(D)
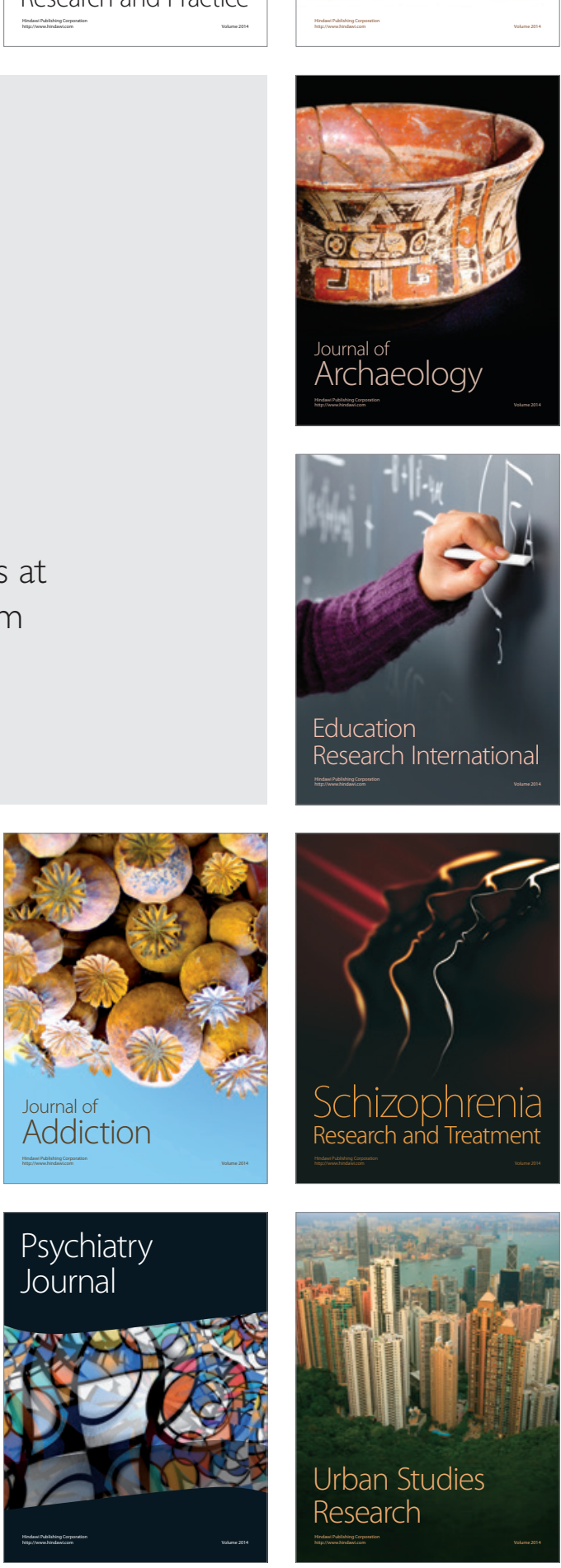